\title{
UPAYA MENINGKATKAN HASIL BELAJAR MATEMATIKA DENGAN MENERAPKAN MODEL PEMBELALAJARAN LANGSUNG MENGGUNAKAN MEDIA MOBIL GARIS BILANGAN TAHUN PELAJARAN 2016/2017
}

\author{
OLEH : Agung Riadin*, Uswatun Nisa**
}

\begin{abstract}
Abstrak
Penelitian ini bertujuan untuk: (1) mendeskripsikan aktivitas belajar peserta didik kelas IV SDN 1 Sari Makmur selama proses pembelajaran matematika dengan menerapkan model pembelajaran langsung menggunakan media mobil garis bilangan, (2) mengetahui peningkatan hasil belajar Matematika pada peserta didik kelas IV SDN 1 Sari Makmur setelah menerapkan model pembelajaran langsung menggunakan media mobil garis bilangan.

Penelitian ini dilakukan pada minggu ke-4 Bulan April 2017 yang berlokasi di SDN 1 Sari Makmur, Jl. Tambun Bungai No. 02 Desa Sari Makmur Kecamatan Mantangai Kabupaten Kapuas. Jenis Penelitian ini adalah Penelitian Tindakan Kelas (PTK) dengan subjek penelitian seluruh peserta didik berjumlah 22 orang peserta didik, 13 orang laki-laki dan 9 orang perempuan. Teknik pengumpulan data dalam penelitian ini menggunakan observasi dan tes. Teknik analisis data menggunakan analisis data kualitatif dan analisis data kuantitatif.

Hasil penelitian ini menunjukan bahwa : (1) Aktivitas belajar Matematika dengan menerapkan Model Pembelajaran Langsung menggunakan Media Mobil Garis Bilangan pada peserta didik kelas IV SDN 1 Sari Makmur Tahun Pelajaran 2016/2017 lebih baik dan mengalami peningkatan disetiap siklus. Pada siklus I peserta didik memperoleh nilai dengan rata - rata 3,66 dengan kategori baik, dan siklus II peserta didik memperoleh nilai dengan rata - rata 3,88 dengan kategori baik (2) ada peningkatan hasil belajar Matematika dengan menerapkan Model Pembelajaran Langsung menggunakan Media Mobil Garis Bilangan pada peserta didik kelas IV SDN 1 Sari Makmur Tahun Pelajaran 2016/2017, ini terbukti dari hasil belajar pada pra tindakan diperoleh rata - rata 28 dengan ketuntasan klasikal $14 \%$, pada siklus I diperoleh rata - rata 57 dengan ketuntasan klasikal $45 \%$, dan pada siklus II diperoleh rata - rata 98 dengan ketuntasan klasikal yaitu $100 \%$.
\end{abstract}

\section{Kata Kunci : Hasil Belajar, Model Pembelajaran Langsung, Media Mobil Garis Bilangan, Matematika}

\section{PENDAHULUAN}

Pendidikan merupakan salah satu
upaya untuk meningkatkan
pualitas
perbaikan sumber daya manusia. Pendidikanjuga merupakan bagian dari seluruhrangkaian pembangunan nasional yaitu pembangunan manusia seutuhnya danpembangunan seluruh masyarakat pada umumnya.

Melihat kondisi dunia pendidikan saat ini, banyak hambatan-hambatan yang dapat mengganggu berjalannya tujuan pendidikan, seperti dalam proses belajar-mengajar ada kalanya guru mengalami kesulitan memenuhi tercapainya tujuan pembelajaran. 
Begitu juga peserta didik merasa kesulitan dalam menguasai suatu materi pelajaran, terutama dalam mata pelajaran matematika. Padahal, matematika merupakan salah satu bidang penting dalam dunia pendidikan di Indonesia .

Mata pelajaran matematika perlu diberikan kepada semua peserta didik mulai dari sekolah dasar untuk membekali peserta didik dengan kemampuan berpikir logis, analitis, sistematis, kritis, dan kreatif, serta kemampuan bekerjasama. Kompetensi tersebut diperlukan agar peserta didik dapat memiliki kemampuan memperoleh, mengelola, dan memanfaatkan informasi untuk bertahan hidup pada keadaan yang selalu berubah, tidak pasti, dan kompetitif.

Berdasarkan hasil observasi pada kelas IV SDN 1 Sari Makmur yang berjumlah 22 orang terdiri dari 13 orang lakilaki dan 9 orang perempuan, peneliti menemukan beberapa masalah dalam pembelajaran Matematika, khususnya pada materi Operasi Hitung Bilangan Bulat. Dalam proses pembelajaran, masih terlihat kurangnya penerapan model serta penggunaan media yang bervariasi, masih rendahnya minat belajar peserta didik terhadap mata pelajaran Matematika dan aktivitas peserta didik dalam pembelajaran masih kurang aktif. Akibatnya hasil belajar peserta didik masih rendah.

Berdasarkan hasil belajar peserta didik yang diperoleh dari ulangan harian pada mata pelajaran Matematika masih banyak peserta didik yang Tidak Tuntas. Peneliti melihat ada $64 \%$ (14 orang) dari 22 peserta didik yang nilainya dibawah kriteria ketuntasan minimal (KKM) dan $36 \%$ (8 orang) dari 22 peserta didik yang nilainya diatas ketuntasan kriteria minimal (KKM).

$$
\text { peserta didik terhadap }
$$

pembelajaran yang dilakukan guru
Sedangkan kriteria ketuntasan minimal (KKM) pada mata pelajaran Matematika yang terdapat di SDN 1 Sari Makmur adalah 60 .

Mengingat pentingnya pelajaran Matematika, perlu adanya tindakan guru untuk mengadakan perbaikan dalam proses pembelajaran agar pembelajaranyang diberikanguru dapat berhasilbaik itu dari tingkat keberhasilan pemahaman, penguasaan materi, dan hasil belajar sesuai dengan kompetensi dasar, maka guru hendaknya mengemas proses pembelajaran dengan menerapkan model yang tepat dan menarik penyajiannya serta dilengkapi dengan penyediaan media pembelajaran.

Salah satu model pembelajaran yang dapat diterapkan untuk meningkatkan hasil belajar peserta didik pada materi operasi hitung bilangan bulat yaitu model pembelajaran langsung, dimana dalam pelaksanaannya, guru terlebih dulu menjelaskan materi pelajaran, mendemonstrasikan penggunaan media pembelajaran dengan benar dan memberikan bimbingan kepada peserta didik untuk berlatih dan terlibat langsung dalam kegiatan pembelajaran dengan menggunakan media yang telah disediakan. Dari penerapan model pembelajaran langsung, guru dapat mengecek sejauh mana pemahaman peserta didik melalui bimbingan pelatihan dalam proses pembelajaran. Adapun penggunaan media pembelajaran matematika khususnya pada operasi hitung bilangan bulat ini dapat berupa mobil garis bilangan. Diharapkan dengan penerapan model pembelajaran dan penggunaan media pembelajaran ini akan membantu memperjelas materi pelajaran yang akan disampaikan, memudahkan pemahaman peserta didik juga membuat peserta didik senang sehingga minat semakin meningkat sehingga proses pembelajaran matematika pada operasi 
hitung bilangan bulat menjadi lebih bermakna dan efektif untuk meningkatkan hasil belajar peserta didik.

Melihat latar belakang masalah dan dari fenomena yang terjadi,maka peneliti tertarik untuk melakukan penelitian dengan judul "Upaya Meningkatkan Hasil Belajar Matematika Dengan Menerapkan Model Pembelajaran Langsung Menggunakan Media Mobil Garis Bilangan Pada Kelas IV SDN 1 Sari Makmur Tahun Pelajaran 2016/2017”.

\section{METODE PENELITIAN}

Penelitian ini dilaksanakan pada bulan Maret sampai dengan Mei Tahun Pelajaran 2016/2017. Jenis penelitian pada penelitian ini adalah menggunakan metode Penelitian Tindakan Kelas (PTK). Desain penelitian ini mengacu pada model John Elliot (Dadang Yudhistira, 2013:46) terdiri dari empat tahapan yaitu perencanaan, pelaksanaan tindakan, pengamatan, dan refleksi. Penelitian ini dilakukan di SDN 1 Sari Makmur J1. Tambun Bungai No. 02 Desa Sari Makmur Kecamatan Mantangai Kabupaten Kapuas dengan subjek penelitian peserta didik kelas IV SDN 1 Sari Makmur yang berjumlah 22 orang terdiri dari 13 orang laki-laki dan 9 orang perempuan.

Teknik pengumpulan data dengan menggunakan Observasi dan Tes. Untuk melakukan observasi ini peneliti meminta guru kelas IV dan teman sejawat sebagai pengamat untuk mengamati aktivitas peserta didik dan guru dalam kegiatan pembelajaran. Dalam pelaksanaan tes, peneliti melakukan tes dengan menggunakan pre test dan post test.

Teknik analisis data yang yang digunakan dalam penelitian ini adalah analisis kualitatif dan analisis kuantitatif. Data yang dikumpulkan dari setiap siklus akan dianalisis menggunakan metode Mixed Methods atau metode kombinasi antara kualitatif dan kuantitatif. Creswell (Sugiyono, 2013:244) menyatakan bahwa "Metode penelitian kombinasi (mixed methods) akan berguna bila metode kuantitatif atau metode kualitatif secara sendiri-sendiri tidak cukup akurat digunakan untuk memahami permasalahan penelitian atau dengan menggunakan metode kualitatif dan kuantitatif secara kombinasi akan dapat memperoleh pemahaman yang paling baik sehingga diperoleh data yang lebih baik komprehensif, valid, reliable dan obyektif (bila dibandingkan dengan satu metode)".

\section{Data Kualitatif}

Data Kualitatif diperoleh dari aktivitas peneliti dan aktivitas terhadap peserta didik serta respon peserta didik selama proses belajar mengajar dengan menganalisis hasil belajar yang dilihat dalam proses belajar mengajar dengan menerapkan model pembelajaran langsung menggunakan media mobil garis bilangan. Untuk menilai aktivitas guru dan peserta didik dalam pembelajaran digunakan ratarata dengan kategori sebagai berikut :

$$
\begin{array}{ll}
\text { Kurang baik } & =1-1,9 \\
\text { Cukup Baik } & =2-2,9 \\
\text { Baik } & =3-3,9 \\
\text { Sangat Baik } & =4
\end{array}
$$

\section{Data Kuantitatif}

Data kuantitatif berasal dari hasil tes yang diberikan pada setiap akhir siklus kegiatan. Hal ini dilakukan untuk mengetahui peningkatan hasil belajar Matematika peserta didik dengan menerapkan model pembelajaran langsung menggunakan media mobil garis bilangan. Adapun rumus yang digunakan untuk menghitung ketuntasan individual tingkat ketercapaian klasikal 
peserta didik dihitung dengan rumus sebagai berikut :

a. Menghitung nilai rata-rata kelas :

$\mathrm{M}=\frac{\sum x}{n}$

Keterangan :

$\mathrm{M}=$ nilai rata-rata

$\sum x=$ jumlah semua nilai siswa

$\mathrm{n}=$ jumlah siswa

Sumber : Yudhistira, (2013:128)

b. Menghitung persentase ketuntasan belajar peserta didik secara klasikal:

Menurut Trianto, (2010:241) setiap peserta didik dikatakan tuntas belajarnya (ketuntasan klasikal) jika dalam kelas tersebut terdapat $\geq 85 \%$ peserta didik telah tuntas belajarnya.

Menghitung

persentase ketuntasan belajar peserta didik untuk ketuntasan klasikal dengan rumus :

$\mathrm{TB}=\frac{\sum s \geq 60}{N} \times 100 \%$

Keterangan :

$\sum s \quad=$ Jumlah peserta didik yang mendapat nilai sama dengan 60

$\mathrm{N} \quad=$ Banyak peserta didik

$100 \%=$ Bilangan tetap (persentase)

$\mathrm{TB}=$ Ketuntasan belajar klasikal minimal $85 \%$

Kriteria ketuntasan

- 85-100 = Tuntas

- $0-84=$ Tidak Tuntas

\section{HASIL DAN PEMBAHASAN}

\section{Pra Tindakan}

Pada tahap pra tindakan membuktikan bahwa masih rendahnya kemampuan peserta didik dalam pembelajaran Matematika pada materi pengurangan bilangan bulat. Hal ini dibuktikan pada saat pemberian tes kegiatan pra tindakan, peserta didik masih banyak yang tidak mengalami ketuntasan dalam pembelajaran sesuai dengan ketuntasan KKM yaitu 60 dan ketuntasan klasikal 85\%. Data hasil nilai rata-rata peserta didik pada tes awal (pre test) adalah 28 dan ketuntasan belajar yaitu $14 \%$.

\section{Siklus 1}

Dengan menerapkan model pembelajaran langsung menggunakan media mobil garis bilangan, aktivitas guru dan peserta didik pada siklus 1 mengalami peningkatan dari tahap sebelumnya. Aktivitas guru dan peserta didik pada siklus I oleh pengamat I memperoleh nilai rata-rata 3,77 untuk aktivitas guru dan 3,61 untuk aktivitas peserta didik. Dari pengamat 2 memperoleh nilai rata-rata 3,83 utuk aktivitas guru dan 3,72 untuk aktivitas peserta didik.

Berdasarkan hasil perhitungan rata - rata Siklus 1, hasil nilai rata - rata peserta didik pada tes siklus 1 adalah 57 dengan Ketuntasan klasikal $45 \%$ yang menandakan bahwa proses pembelajaran masih belum tuntas yaitu belum mencapai KKM, sehingga masih perlu dioptimalkan lagi pada siklus II.

\section{Siklus II}

Pelaksanaan siklus II ini dimaksud untuk melakukan penelitan pada siklus 1 yang dipandang belum berhasil oleh penulis, karena rata - rata hasil belajar Matematika peserta didik pada siklus 1 belum mencapai nilai 60 .

Pada tahap siklus II aktivitas guru dan peserta didik mengalami peningkatan yang baik, dengan penilaian oleh pengamat I memperoleh nilai rata-rata 3,94 untuk aktivitas guru dan 3,83 untuk aktivitas 
peserta didik. Dari pengamat II memperoleh nilai rata-rata 3,94 untuk aktivitas guru dan 3,94 untuk aktivitas peserta didik. Maka dari itu pada siklus II ini aktivitas guru dan peserta didik telah memperoleh hasil yang memuaskan dengan kategori baik.

Pada Siklus II, hasil nilai rata - rata peserta didik adalah 98 dengan Ketuntasan klasikal $100 \%$ yang menandakan bahwa proses pembelajaran dinyatakan tuntas yaitu mencapai KKM. Berdasarkan hasil tersebut, dapat dilihat bahwa terjasi peningkatan aktivitas guru dan peserta didik dari siklus I ke siklus II dan adanya peningkatan hasil belajar Matematika dengan menerpakna model pembelajaran langsung menggunakan media mobil garis bilangan.

\section{KESIMPULAN}

Berdasarkan hasil penelitian yang telah dibahas, maka dapat disimpulkan :

1. Aktivitas belajar Matematika menjadi baik dengan menerapkan Model Pembelajaran Langsung menggunakan Media Mobil Garis Bilangan pada materi ajar pengurangan bilangan bulat di SDN 1 Sari Makmur kelas IV Tahun Pelajaran 2016/2017. Hal tersebut terlihat pada aktivitas peserta didik pada Siklus I dengan kategori baik dengan skor rata-rata 3,66 dan pada siklus II ada peningkatan skor rata-rata 3,88 dengan kategori baik

2. Ada peningkatan hasil belajar Matematika dengan menerapkan Model Pembelajaran Langsung menggunakan Media Mobil Garis Bilangan pada materi ajar pengurangan bilangan bulat di SDN 1
Sari Makmur kelas IV Tahun Pelajaran 2016/2017. Rata - rata pada pre test mendapat hasil 28 dengan persentase ketuntasan klasikal $14 \%$. Pada siklus I diperoleh hasil rata - rata 57 dengan persentase ketuntasan klasikal $45 \%$ dan pada siklus II diperoleh hasil rata - rata 98 dengan persentase ketuntasan klasikal $100 \%$

\section{DAFTAR PUSTAKA}

Diana. (2014). Penerapan Model Pengajaran Langsung Menggunakan Garis bilangan Untuk Meningkatkan Kemampuan Siswa Dalam Menyelesaikan Soal Penjumlahan Dan Pengurangan Bilangan Bulat Di Kelas VII SMP Negeri 3 Banawa. Jurnal Elektronik Pendidikan Matematika Tadulako, Vol. 2, No. 1, 13-22.

Sari, Dhany Efita, dkk. (2013). Penggunaan Model Direct Instruction Sebagai Upaya Peningkatan Pemahaman Siswa Melalui Kertas Kerja. Jurnal UNS, Vol 2, No. 1, 11-25.

Sugiyono.(2013).Metode Penelitian Kuantitatif, Kualitatif dan $R \& D$. Bandung : Alfabeta, CV.Bandung

Trianto. (2010). Mendesain Model Pembelajaran Inovatif-Progresif Konsep Landasan dan Implementasinya pada Kurikulum Tingkat Satuan Pendidikan (KTSP). Jakarta : Kencana Prenada Media Group.

Yudhistira, Dadang.(2013).Menulis

Penelitian Tindakan Kelas yang

APIK. Jakarta : PT Gramedia

Widiasarana Indonesia. 
Pedagogik Jurnal Pendidikan, Oktober 2017, Volume 12 No 2 (28-33) 